\section{Susceptibility of Zoysiagrass Germplasm to Large Patch Caused by Rhizoctonia solani}

\author{
Ken Obasa \\ Department of Plant Pathology, Kansas State University, 4024 Throckmorton \\ Plant Sciences Center, Manhattan, KS 66506
}

Jack Fry

Department of Horticulture, Forestry, and Recreation Resources, 2021 Throckmorton Plant Sciences Center, Kansas State University, Manhattan, KS 66506

\section{Megan Kennelly ${ }^{1}$ \\ Department of Plant Pathology, Kansas State University, 4024 Throckmorton Plant Sciences Center, Manhattan, KS 66506}

Additional index words. turfgrass pathology, fungal disease, transition zone, disease management, digital image analysis

\begin{abstract}
Fourteen new zoysiagrass (Zoysia spp.) germplasm lines from parental crosses including $Z$. japonica (Steud.), Z. matrella (L.) Merr., and Z. pacifica (Goudswaard) were evaluated for susceptibility to large patch caused by the fungus Rhizoctonia solani Kühn anastomosis group (AG) 2-2 LP. The germplasm lines were compared with 'Meyer' (Zoysia japonica Steud.), the most widely used cultivar in the transition zone of the United States, under growth chamber and field conditions. Large patch susceptibility in the growth chamber study was estimated five days post-inoculation and thereafter for 25 days. Three pots of each line and 'Meyer' were randomly selected and rated for disease incidence by determining the percentage of individual shoots in each pot with distinct, water-soaked brown lesions on the leaf sheath. Field assessment of large patch susceptibility was carried out weekly and was by direct measurement of patch sizes as well as by digital image analysis of plots for the percentage of diseased turf. All 14 progeny had similar disease levels compared with 'Meyer' in the growth chamber, but only six consistently had disease levels as low as 'Meyer' in the field. Growth chamber results did not correlate to field results.
\end{abstract}

Zoysiagrass (Zoysia spp.) is a warm-season (C4) turfgrass that is popular in the transition zone of the United States (Dunn and Diesburg, 2004; Fry et al., 2008; Patton et al., 2007). Some desirable characteristics of zoysiagrasses include good density and resistance to pests (Fry and Huang, 2004). Zoysiagrass also requires less fertilizer and pesticides compared with some cool-season turfgrass species such as creeping bentgrass (Agrostis stolonifera L.) (Fry et al., 2008).

Large patch, caused by Rhizoctonia solani AG 2-2 LP, is the most common and severe disease of zoysiagrass in the transition zone and everywhere zoysiagrass is used. It can cause large areas of blighted turf in the spring and fall. Typical symptoms appear as light brown to straw-colored sunken patches with or without bright orange margins (Green et al., 1993; Smiley et al., 2005; Tisserat et al., 1994). Patches can range in size up to $6 \mathrm{~m}$ or more in diameter (Green et al., 1993; Tisserat et al., 1994) with healthy turfgrass sometimes scattered within the patches. During summer

Received for publication 8 June 2012. Accepted for publication 23 July 2012.

${ }^{1}$ To whom reprint requests should be addressed; e-mail kennelly@ksu.edu. from $Z$. japonica and one from either a $Z$. matrella cultivar or 'Emerald' (Z. japonica $\times$ $Z$. pacifica). The crosses were made in an effort to develop one or more cultivars with freezing tolerance equivalent to or better than 'Meyer' as well as having good density, fine leaf texture, and quality. In a recent study, Okeyo et al. (2011) determined that several zoysiagrass progeny associated with reciprocal crosses of $Z$. matrella (L.) Merr. $\times$ Z. japonica or 'Emerald' $\times$ 'Meyer' demonstrated freezing tolerance comparable with 'Meyer'. Furthermore, some also were superior to 'Meyer' in fall green color retention but not spring green color onset (Okeyo et al., 2011). In another study, Fry and Cloyd (2011) assessed the susceptibility of a select 14 of the zoysiagrass progeny and 'Meyer' to bluegrass billbug larval damage. The study found that lines 5313-71, DALZ 0102, 532118 , and 5334-59 suffered significantly lower larval damage compared with 'Meyer' during the 2 years of the study.

The objective of this study was to evaluate the susceptibility to large patch of 14 new freeze-tolerant zoysiagrass progeny and 'Meyer' under growth chamber and field conditions. The 14 progeny are a subset of selections made from evaluations of the original 600 zoysiagrass progeny for cold tolerance and the other traits listed at Kansas State University.

\section{Materials and Methods}

\section{Pathogen isolation and storage}

Rhizoctonia solani AG 2-2 LP isolates were recovered from large patch-infected zoysiagrass samples from Kansas in 2008. Leaf sheath sections measuring 1 to $2 \mathrm{~cm}$ with blight symptoms were removed from infected plants, surfaced-sterilized with $0.5 \%$ $\mathrm{NaOCl}$ for $\approx 2 \mathrm{~min}$, blotted dry, and placed on one-fourth strength potato dextrose agar (Difco Laboratories, MD) amended with tetracycline $\left(10 \mathrm{mg} \cdot \mathrm{L}^{-1}\right)$ and streptomycin $\left(10 \mathrm{mg} \cdot \mathrm{L}^{-1}\right)$ (Biotech Research Grade; Fisher Scientific Inc., NJ) (designated as " $1 / 4 \mathrm{PDA}^{++}$"). Cultures were maintained at $23{ }^{\circ} \mathrm{C}$ in the dark. Identification of $R$. solani from cultures was based on hyphal characteristics, nuclear conditions (multinucleate) as described by Martin (1987), hyphal anastomosis and fusion frequency with a known tester isolate belonging to the anastomosis group AG-2-2 LP on agarcoated glass slides (Carling, 1996; Martin and Lucas, 1984), and by polymerase chain reaction using the AG 2-2 LP-specific primer P22-LP developed by Carling et al. (2002). One large patch isolate was then selected from the collection and used to infest oat kernels in glass jars according to the method described by Tisserat et al. (1989). To prepare inoculum, $150 \mathrm{~g}$ of oat kernels mixed with $150 \mathrm{~mL}$ of distilled water in a glass jar was sterilized by steam autoclaving twice at $121{ }^{\circ} \mathrm{C}$ for $30 \mathrm{~min}$. Sterilized oats were inoculated with several agar plugs from plates of $1 / 4 \mathrm{PDA}^{++}$. The glass jars containing the inoculated oat kernels were shaken periodically, as required, to ensure even distribution. 
After $\approx 14 \mathrm{~d}$ of incubation, the infested oat kernels were used, without drying, for inoculation of established progeny turfgrasses in pots and in the field.

\section{Growth chamber studies}

Plant inoculation and disease assessment. Stolons of the 14 new lines and 'Meyer' (see Tables 1 to 4) were collected in October of 2008 and November of 2009, respectively, from the edges of established field plots measuring $1.5 \mathrm{~m} \times 1.5 \mathrm{~m}$ with three replicate plots each at the Rocky Ford Turfgrass Research Station in Manhattan, KS (Okeyo et al., 2011). Stolons were rinsed under tap water to remove soil debris, surface-sterilized with $0.5 \% \mathrm{NaOCl}$ for $3 \mathrm{~min}$, and finally rinsed in two changes of distilled water. Prepared stolons were subsequently propagated in potting media (Metro Mix 510; SUN GRO, WA) contained in $5 \mathrm{~cm} \times 5$-cm plastic pots and kept under an intermittent mist system in the greenhouse at $25{ }^{\circ} \mathrm{C}$ for $\approx 2$ months. Pots with stolon sections containing three to 10 shoots were subsequently removed from the mist chamber and maintained at $28{ }^{\circ} \mathrm{C}$ and 16-h photoperiod achieved with supplemental lighting of up to $580 \mu \mathrm{mol} \cdot \mathrm{m}^{-2} \cdot \mathrm{s}^{-1}$ at the canopy level (Zhang, 2007) in a greenhouse for an additional 3 months before inoculation. Grasses were fertilized once with urea to provide nitrogen $(\mathrm{N})$ at $49 \mathrm{~kg} \cdot \mathrm{ha}^{-1}$ immediately after transfer to the greenhouse. Pots were watered twice a week and grasses were maintained at a height of $\approx 2 \mathrm{~cm}$ using scissors.

Each zoysiagrass line was inoculated with eight to 10 infested or non-infested sterile oat kernels by placing the kernels on the soil surface in each pot. A total of 18 pots of each zoysiagrass line was placed in separate plastic trays, filled with water to a depth of $2 \mathrm{~cm}$, and covered with a clear plastic lid to maintain a high relative humidity. The plastic trays were arranged in a complete randomized design and maintained at $25{ }^{\circ} \mathrm{C}$ and a 13 -h photoperiod in a Conviron ATC60 growth chamber (Conviron, Canada).

After $5 \mathrm{~d}$, and at 5-d intervals thereafter for $25 \mathrm{~d}$, three pots of each line were randomly selected and removed from the growth chamber for destructive sampling. They were rated for disease incidence by determining the percentage of individual shoots in each pot with distinct, water-soaked brown lesions on the leaf sheath according to the method of Green et al. (1993). To verify the causal pathogen, representative samples of infected tissues of each line were surface-sterilized and incubated on $1 / 4 \mathrm{PDA}^{++}$at $25{ }^{\circ} \mathrm{C}$ for re-isolation of R. solani. After $25 \mathrm{~d}$, the three uninoculated pots of each zoysia line were also removed from the growth chamber and similarly rated for disease incidence. This study was conducted in 2009 and repeated in 2010.

\section{Field studies}

Plot inoculation and disease assessment. The study was conducted at the Rocky Ford Turfgrass Research Center in Manhattan, KS (long. $39.13^{\circ} \mathrm{N}$, lat. $96.36^{\circ} \mathrm{W}$ ). Soil at the site was a Chase silt loam (fine, smectitic, mesic, Aquertic Argiudoll) with a $\mathrm{pH}$ of 7.3. Plots of the 14 new zoysiagrass progeny and 'Meyer' measuring $1.5 \mathrm{~m} \times 1.5 \mathrm{~m}$ were used for the study. Each plot was established from 166 -cm-diameter plugs planted in a $30.5 \mathrm{~cm} \times$ $30.5-\mathrm{cm}$ area at the center of each plot in 2007 (Okeyo et al., 2011). The plots were arranged in a randomized complete block design with three replicates per line and a $0.6-\mathrm{m}$ alley between each plot. The plots were mowed twice every week at $1.4 \mathrm{~cm}$. In-ground irrigation was used to prevent stress and supplement rainfall to provide $2.5 \mathrm{~cm}$ of water per week. Plots were fertilized in July and August of each year with urea to provide a total of $49 \mathrm{~kg} \mathrm{~N} /$ ha per year.

For the establishment of large patch disease, all the plots were inoculated in September of 2008. Inoculation was performed by placing 8 to $10 \mathrm{~g}$ of infested oat kernels in a small furrow of $\approx 5$ to $7 \mathrm{~cm}$ diameter, made using a hand trowel, between the turf and thatch layer at the center of each plot. Plots were subsequently irrigated daily for $\approx 10 \mathrm{~d}$ after inoculation to promote the establishment of disease.

In the spring of 2009, patch sizes in progeny field plots were measured weekly using a meter rule and expressed as the average patch diameter along two perpendicular axes. Additionally, analysis of digital images of plots was carried out. Patch symptoms within a $65 \mathrm{~cm} \times 75-\mathrm{cm}$ rectangle in the center of plots were photographed weekly using the automatic settings of a Nikon D70s digital camera (Nikon Inc., Japan) at $1.2 \mathrm{~m}$ above the turf. Plots were manually brushed and air-blown with a motorized blower to remove dead grass clippings before being photographed. This was necessary to avoid error in large patch estimations resulting from contributions from the color of the dead clippings. The digital images were subsequently analyzed with SigmaScan Pro Version 5.0 software (SPSS, Chicago, IL) using a SigmaScan Pro macro for batch analysis of digital images named "Turf Analysis" by Karcher and Richardson (2005). The threshold settings of Karcher and Richardson (2005) were adjusted (hue: 0 to 53 and saturation: 0 to 57 ) to select for pixels representing patch symptoms within each digital image. In the spring of 2010, however, large patch assessment within the plots was carried out only by the method of digital analysis of patch images as a result of poorly defined patch margins that prevented accurate size measurements. Data collected by digital image analysis represented the percentage of diseased turf within each plot.

Table 1. Large patch (caused by $R$. solani AG 2-2 LP) disease incidence of new zoysiagrass lines and 'Meyer' under growth chamber conditions ${ }^{\mathrm{z}}$ in 2009.

\begin{tabular}{|c|c|c|c|c|c|c|}
\hline \multirow[b]{3}{*}{ Progeny/parent ${ }^{\mathrm{x}}$} & \multicolumn{5}{|c|}{ Disease incidence $(\%)^{\mathrm{y}}$} & \multirow[b]{3}{*}{ AUDPC $^{\mathrm{w}}$} \\
\hline & \multicolumn{5}{|c|}{ Days after inoculation (DAI) } & \\
\hline & 5 & 10 & 15 & 20 & 25 & \\
\hline \multicolumn{7}{|l|}{ Cavalier $\times$ Chinese Common } \\
\hline $5311-16$ & $2.4 \mathrm{c}$ & 25.4 & 51.7 & 47.5 & 55.3 & 153.4 bcde \\
\hline $5312-55$ & $2.1 \mathrm{c}$ & 57.1 & 60.7 & 56.7 & 43.6 & $197.4 \mathrm{ab}$ \\
\hline \multicolumn{7}{|l|}{ Zorro $\times$ Meyer } \\
\hline $5313-23$ & $18.3 \mathrm{ab}$ & 49.1 & 45.7 & 55.6 & 60.2 & $189.6 \mathrm{abc}$ \\
\hline $5313-34$ & $7.3 \mathrm{bc}$ & 49.5 & 59.7 & 46.4 & 50.0 & $184.2 \mathrm{abcd}$ \\
\hline $5313-71$ & $4.2 \mathrm{c}$ & 29.3 & 59.5 & 49.4 & 43.5 & $145.6 \mathrm{cde}$ \\
\hline $5313-46$ & $0.0 \mathrm{c}$ & 42.1 & 53.1 & 60.5 & 46.3 & 178.9 abcd \\
\hline \multicolumn{7}{|l|}{ Emerald $\times$ Meyer } \\
\hline $5321-9$ & $4.8 \mathrm{c}$ & 54.7 & 61.8 & 69.9 & 39.8 & $208.7 \mathrm{a}$ \\
\hline $5321-18$ & N/A & 25.0 & 37.6 & 52.3 & N/A & $\mathrm{N} / \mathrm{A}^{\mathrm{v}}$ \\
\hline \multicolumn{7}{|l|}{ Meyer $\times 8501$} \\
\hline $5324-26$ & $0.0 \mathrm{c}$ & 41.6 & 62.1 & 56.5 & 54.2 & $187.4 \mathrm{abcd}$ \\
\hline $5324-32$ & $20.5 \mathrm{a}$ & 21.0 & 44.3 & 51.6 & 53.0 & $144.8 \mathrm{de}$ \\
\hline \multicolumn{7}{|l|}{ Meyer $\times 8508$} \\
\hline $5325-11$ & $0.0 \mathrm{c}$ & 57.3 & 55.6 & 55.4 & 59.1 & $197.9 \mathrm{ab}$ \\
\hline \multicolumn{7}{|l|}{ Meyer $\times$ Diamond } \\
\hline $5327-67$ & $12.0 \mathrm{abc}$ & 40.6 & 53.9 & 51.8 & 62.7 & $183.7 \mathrm{abcd}$ \\
\hline \multicolumn{7}{|l|}{ Emerald $\times$ Zenith } \\
\hline $5334-59$ & $0.0 \mathrm{c}$ & 32.2 & 41.6 & 45.2 & 53.1 & $145.6 \mathrm{cde}$ \\
\hline DALZ 0102 & $0.0 \mathrm{c}$ & 34.4 & 47.8 & 50.1 & 40.1 & $152.3 \mathrm{cde}$ \\
\hline Meyer & $6.6 \mathrm{bc}$ & 43.6 & 44.9 & 58.0 & 49.5 & $174.4 \mathrm{abcd}$ \\
\hline
\end{tabular}

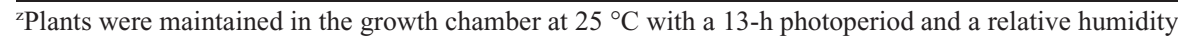
of $\approx 95 \%$.

${ }^{y}$ Expressed as a percentage of individual shoots showing water-soaked sheath blighting symptoms averaged across three replicated pots destructively sampled at each time point (DAI) for each zoysiagrass line. One-way analysis of variance was used to compare percent disease incidence. Values followed by the same letter in a column are not statistically different $(P<0.05)$. Values in the same column and with no letters are not statistically different $(P<0.05) ; \mathrm{N} / \mathrm{A}=$ data not available as a result of insufficient experimental pots of the zoysiagrass line.

${ }^{x}$ Meyer, DALZ 0102, and Anderson (Chinese common) are Z. japonica. Zorro, 8501, 8508, and Diamond are Z. matrella.

wArea under disease progress curve (AUDPC). Calculated as $\sum\left[\left(y_{i}+y_{i+1}\right) / 2\right]\left[t_{i+1}-t_{i}\right]$, where $i=1,2,3, \ldots$, $n-1, y_{\mathrm{i}}$ is the amount of disease (incidence) and $t_{i}$ is the time of the $i$ th rating. Values followed by same letter in a column are not statistically different $(P<0.05)$. There was no significant difference among progeny and Meyer at 10, 15, 20, and 25 DAI.

${ }^{v}$ Disease incidence values available for only three data points $(10,15$, and $20 \mathrm{DAI})$ as a result of shortage of progeny plant materials. Consequently, the AUDPC value is not shown as a result of incomplete data. 
Data analysis. Statistical analysis of data were performed with Minitab Version 16 (Minitab Inc., PA) statistical software. The area under the disease progress curve (AUDPC) for each zoysia line from the growth chamber and field studies was calculated using the method of Madden et al. (2007) with the formula $\Sigma\left[\left(y_{i}+y_{i+1}\right) / 2\right]\left[t_{i+1}-t_{i}\right]$, where $i=$ $1,2,3, \ldots, n-1, y_{\mathrm{i}}$ is the amount of disease incidence (growth chamber) or the percentage of diseased turf (field) and $t_{i}$ is the time of the $i$ th rating, providing an estimate of cumulative disease severity over time. Data obtained following the analysis of the digital images were subjected to analysis of variance (ANOVA). AUDPC is a measure of the cumulative season-long or experimentlong disease development over time. Oneway ANOVA was used for comparing the means (with Fisher's individual error rate at $P \leq 0.05)$.

To determine if there was a statistical association between the performance of the zoysiagrass progeny under growth chamber and field conditions, we performed correlation analysis between the growth chamber and field AUDPC values for the 2009 and 2010 studies using Pearson's product moment correlation coefficient. Additionally, we evaluated the correlation in large patch AUDPC between growth chamber experiments and between results in the field in 2009 and 2010.

\section{Results}

\section{Growth chamber inoculation and disease assessment}

On all rating dates except $5 \mathrm{~d}$ after inoculation (DAI), in 2009, there were no significant differences among any lines (Table 1). At $5 \mathrm{~d}$ after inoculation, the percentage of individual shoots in each pot with distinct, water-soaked brown lesions on the leaf sheath was significantly higher for 5324-32 compared with 'Meyer' and many other lines (Table 1). None of the new lines had AUDPC values that were significantly different from 'Meyer'. The AUDPC values for DALZ 0102, 5313-71, 5334-59, and 5324-32 were not statistically different from 'Meyer' but were significantly lower than those of 5325-11 and 5312-55 (Table 1).

In the 2010 study, the overall performance of each zoysiagrass for the duration of the study, represented by their respective AUDPC values, was not significantly different from that of 'Meyer' (Table 2). Consistent with the 2009 result, line 5324-32 had a significantly higher disease incidence at 5 DAI compared with 'Meyer' and all of the other lines. Additionally, at 10 DAI, progeny 5313-46 also had a significantly higher disease incidence compared with 'Meyer', whereas 5324-26 at 15 DAI and 5321-9 at 25 DAI had significantly lower disease incidence than 'Meyer' (Table 2).

\section{Field disease assessment}

2009 assessment. Patch sizes in the new lines were not significantly different from those of 'Meyer' on 12 and 19 June (Table 3).

Table 2. Large patch (caused by $R$. solani AG 2-2 LP) disease incidence of new zoysiagrass lines and 'Meyer' under growth chamber conditions ${ }^{\mathrm{z}}$ in 2010.

\begin{tabular}{|c|c|c|c|c|c|c|}
\hline \multirow[b]{3}{*}{ Progeny/parent ${ }^{\mathrm{x}}$} & \multicolumn{5}{|c|}{ Disease incidence $(\%)$} & \multirow[b]{3}{*}{ AUDPC $^{\mathrm{w}}$} \\
\hline & \multicolumn{5}{|c|}{ Days after inoculation (DAI) } & \\
\hline & 5 & 10 & 15 & 20 & 25 & \\
\hline \multicolumn{7}{|l|}{ Cavalier $\times$ Chinese Common } \\
\hline $5311-16$ & $0.0 \mathrm{~b}$ & $22.2 \mathrm{abcd}$ & $39.9 \mathrm{ab}$ & 33.3 & $22.6 \mathrm{bc}$ & $106.8 \mathrm{abc}$ \\
\hline $5312-55$ & $0.0 \mathrm{~b}$ & $14.7 \mathrm{bcd}$ & $30.6 \mathrm{ab}$ & 38.3 & $21.4 \mathrm{bc}$ & $94.3 \mathrm{abcd}$ \\
\hline \multicolumn{7}{|l|}{ Zorro $\times$ Meyer } \\
\hline $5313-34$ & $0.0 \mathrm{~b}$ & $34.1 \mathrm{ab}$ & $36.5 \mathrm{ab}$ & 52.8 & $21.0 \mathrm{bc}$ & $133.9 \mathrm{ab}$ \\
\hline $5313-71$ & $0.0 \mathrm{~b}$ & $6.1 \mathrm{~cd}$ & $27.3 \mathrm{ab}$ & 23.3 & $31.8 \mathrm{abc}$ & $72.6 \mathrm{~cd}$ \\
\hline $5313-46$ & $0.0 \mathrm{~b}$ & $40.5 \mathrm{a}$ & $35.9 \mathrm{ab}$ & 46.7 & $27.8 \mathrm{abc}$ & $137.0 \mathrm{a}$ \\
\hline \multicolumn{7}{|l|}{ Emerald $\times$ Meyer } \\
\hline $5321-9$ & $0.0 \mathrm{~b}$ & $16.7 \mathrm{abcd}$ & $39.7 \mathrm{ab}$ & 35.7 & $9.4 \mathrm{c}$ & $96.8 \mathrm{abc}$ \\
\hline $5321-18$ & $0.0 \mathrm{~b}$ & $0.0 \mathrm{~d}$ & $18.7 \mathrm{bc}$ & 17.8 & $26.8 \mathrm{abc}$ & $49.9 \mathrm{~cd}$ \\
\hline \multicolumn{7}{|l|}{ Meyer $\times 8501$} \\
\hline $5324-26$ & $0.0 \mathrm{~b}$ & $0.0 \mathrm{~d}$ & $3.3 \mathrm{c}$ & 29.0 & $19.4 \mathrm{bc}$ & $42.0 \mathrm{~d}$ \\
\hline $5324-32$ & $5.7 \mathrm{a}$ & $19.4 \mathrm{abcd}$ & $47.0 \mathrm{a}$ & 20.0 & $36.9 \mathrm{ab}$ & $107.7 \mathrm{abc}$ \\
\hline \multicolumn{7}{|l|}{ Meyer $\times 8508$} \\
\hline $5325-11$ & $0.0 \mathrm{~b}$ & $22.9 \mathrm{abcd}$ & $35.6 \mathrm{ab}$ & 34.1 & $42.4 \mathrm{ab}$ & $113.8 \mathrm{abc}$ \\
\hline \multicolumn{7}{|l|}{ Meyer $\times$ Diamond } \\
\hline $5327-67$ & $0.0 \mathrm{~b}$ & $26.7 \mathrm{abc}$ & $19.8 \mathrm{bc}$ & 15.3 & $22.9 \mathrm{bc}$ & $73.2 \mathrm{bcd}$ \\
\hline \multicolumn{7}{|l|}{ Emerald $\times$ Zenith } \\
\hline $5334-59$ & $0.0 \mathrm{~b}$ & $0.0 \mathrm{~d}$ & $20.9 \mathrm{bc}$ & N/A & $21.5 \mathrm{bc}$ & $N / A^{v}$ \\
\hline DALZ0102 & $0.0 \mathrm{~b}$ & $4.8 \mathrm{~cd}$ & $19.3 \mathrm{bc}$ & 25.7 & $37.3 \mathrm{ab}$ & $68.5 \mathrm{~cd}$ \\
\hline Meyer & $0.0 \mathrm{~b}$ & $12.2 \mathrm{bcd}$ & $33.7 \mathrm{ab}$ & 26.4 & $42.4 \mathrm{ab}$ & $93.6 \mathrm{abcd}$ \\
\hline
\end{tabular}

"Plants were maintained in the growth chamber at $25^{\circ} \mathrm{C}$ with a 13 -h photoperiod and a relative humidity of $\approx 95 \%$.

${ }^{y}$ Values expressed as a percentage of individual plants showing water-soaked sheath blighting symptoms averaged across three replicated pots destructively sampled at each time point (DAI) for each zoysiagrass line. One-way analysis of variance was used to compare percent disease incidence. Values followed by the same letter in a column are not statistically different $(P<0.05)$. Values in the same column and with no letters are not statistically different $(P<0.05) ; \mathrm{N} / \mathrm{A}=$ not available as a result of insufficient experimental pots of the zoysiagrass line.

${ }^{\times}$Meyer, DALZ 0102, and Anderson (Chinese common) are Z. japonica. Zorro, 8501, 8508, and Diamond are Z. matrella.

${ }^{\text {w}}$ Area under disease progress curve (AUDPC). Calculated as $\sum\left[\left(y_{i}+y_{i+1}\right) / 2\right]\left[t_{i+1}-t_{i}\right]$, where $i=1,2,3, \ldots$, $n-1, y_{\mathrm{i}}$ is the amount of disease (incidence) and $t_{i}$ is the time of the $i$ th rating. Values followed by similar letter in a column are not statistically different $(P<0.05)$. There was no significant difference among progeny and Meyer at 20 DAI.

vDisease incidence values available for only four data points $(5,10,15$, and $25 \mathrm{DAI})$ as a result of shortage of progeny plant materials. Consequently, the AUDPC value is not shown as a result of incomplete data.

Furthermore, the percentage of diseased turf, as measured by image analysis, was not significantly different among the new lines and 'Meyer' with the exceptions of 5312-55 on 21 June, 5311-16 on 27 June, and 5321-9 on 3 July, which were higher than 'Meyer' (Table 3). No progeny lines had an AUDPC value significantly different from 'Meyer'. Progeny 5313-71 had a significantly lower AUDPC value than 5312-55.

2010 assessment. The percentage of diseased turf was significantly lower for 'Meyer' compared with nine new lines (5313-71, 531346, 5327-67, 5325-11, 5324-32, DALZ 0102, 5324-26, 5321-9, and 5313-23) on 1 May, six new lines (5313-71, 5313-46, 5327-67, 532511, DALZ 0102, and 5321-9) on 7 May, and seven new lines (5313-71, 5313-46, 5327-67, 5325-11, 5324-32, 5324-26, and 5321-18) on 28 May (Table 4). By 24 June, there was no difference in the percentage of diseased turf among the new lines compared with 'Meyer' with the exception of 5313-71, which had a higher percentage of diseased turf (Table 4). The AUDPC of 'Meyer' was also lower than that for eight (5313-71, 5313-46, 5327-67, 5325-11, 5324-32, DALZ 0102, 5324-26, and 5321-9) of the new lines (Table 4). The remaining six of the 14 new lines (5313-23, 5313-34, 5321-18, 5334-59, 5312-55, and
5311-16) had AUDPC values that were not statistically different from that of 'Meyer'.

Correlation analysis. There was no correlation between large patch AUDPC of the progeny in the growth chamber vs. AUDPC in the field ( $r=0.08, P=0.79)$. Additionally, there was no significant correlation in AUDPC between growth chamber experiments $(r=$ $0.46, P=0.09$ ) or between results in the field in 2009 and $2010(r=-0.39, P=0.16)$.

\section{Discussion}

Large patch is widely considered as the most important disease of zoysiagrasses, particularly in the transition zone of the United States (Green et al., 1993). Given that these zoysiagrass progeny were not bred specifically for resistance to large patch disease, it was important to evaluate and compare their susceptibility to large patch with that of 'Meyer', the most widely used zoysiagrass cultivar in the transition zone and which is considered moderately resistant to large patch (Brunneau, 2005; Metz et al., 1993; Reicher, 2004, 2006).

Under growth chamber conditions, designed to be optimal for fungal growth, all progeny performed similarly to 'Meyer' in both experiments. In the growth chamber, three progeny had lower AUDPC values than two other 
Table 3. Large patch (caused by R. solani AG 2-2 LP) diameter and percentage of diseased turf of new zoysiagrass lines and 'Meyer' under field conditions at Manhattan, KS, in 2009.

\begin{tabular}{|c|c|c|c|c|c|c|}
\hline \multirow[b]{2}{*}{ Progeny/parent ${ }^{y}$} & \multicolumn{2}{|c|}{ Avg patch diam $(\mathrm{cm})$} & \multicolumn{3}{|c|}{ Percentage of diseased turf ${ }^{2}$} & \multirow[b]{2}{*}{ AUDPC $^{x}$} \\
\hline & 12 June & 19 June & 21 June & 27 June & 3 July & \\
\hline \multicolumn{7}{|l|}{ Cavalier $\times$ Chinese Common } \\
\hline $5311-16$ & 109.0 & 114.0 & $8.9 \mathrm{ab}$ & $5.9 \mathrm{a}$ & $3.0 \mathrm{~b}$ & $16.7 \mathrm{ab}$ \\
\hline $5312-55$ & 116.5 & 116.0 & $12.2 \mathrm{a}$ & $3.0 \mathrm{ab}$ & $4.9 \mathrm{ab}$ & $31.3 \mathrm{a}$ \\
\hline \multicolumn{7}{|l|}{ Zorro $\times$ Meyer } \\
\hline $5313-23$ & 128.5 & 121.5 & $4.6 \mathrm{ab}$ & $3.8 \mathrm{ab}$ & $1.9 \mathrm{~b}$ & $14.7 \mathrm{ab}$ \\
\hline $5313-34$ & 105.8 & 111.8 & $5.2 \mathrm{ab}$ & $1.7 \mathrm{~b}$ & $5.8 \mathrm{ab}$ & $9.2 \mathrm{ab}$ \\
\hline $5313-71$ & 118.3 & 120.3 & $1.8 \mathrm{~b}$ & $0.5 \mathrm{~b}$ & $2.2 \mathrm{~b}$ & $6.4 \mathrm{~b}$ \\
\hline $5313-46$ & 99.5 & 115.5 & $1.8 \mathrm{~b}$ & $1.7 \mathrm{~b}$ & $2.4 \mathrm{~b}$ & $7.6 \mathrm{ab}$ \\
\hline \multicolumn{7}{|l|}{ Emerald $\times$ Meyer } \\
\hline $5321-9$ & 103.8 & 115.8 & $5.0 \mathrm{ab}$ & $1.9 \mathrm{~b}$ & $10.7 \mathrm{a}$ & $12.0 \mathrm{ab}$ \\
\hline $5321-18$ & 119.3 & 119.5 & $2.8 \mathrm{~b}$ & $1.6 \mathrm{~b}$ & $2.6 \mathrm{~b}$ & $2 a b$ \\
\hline \multicolumn{7}{|l|}{ Meyer $\times 8501$} \\
\hline $5324-26$ & 109.5 & 116.0 & $6.3 \mathrm{ab}$ & $2.1 \mathrm{ab}$ & $7.3 \mathrm{ab}$ & $20.0 \mathrm{ab}$ \\
\hline $5324-32$ & 91.0 & 118.5 & $4.0 \mathrm{ab}$ & $3.4 \mathrm{ab}$ & $1.4 \mathrm{~b}$ & $12.0 \mathrm{ab}$ \\
\hline \multicolumn{7}{|l|}{ Meyer $\times 8508$} \\
\hline $5325-11$ & 104.0 & 120.2 & $4.7 \mathrm{ab}$ & $1.0 \mathrm{~b}$ & $2.9 \mathrm{~b}$ & $8.8 \mathrm{ab}$ \\
\hline \multicolumn{7}{|l|}{ Meyer $\times$ Diamond } \\
\hline $5327-67$ & 128.8 & 127.8 & $3.2 \mathrm{ab}$ & $0.4 \mathrm{~b}$ & $2.8 \mathrm{~b}$ & $9.6 \mathrm{ab}$ \\
\hline \multicolumn{7}{|l|}{ Emerald $\times$ Zenith } \\
\hline 5334-59 & 131.3 & 113.3 & $8.1 \mathrm{ab}$ & $1.5 \mathrm{~b}$ & $7.2 \mathrm{ab}$ & $17.3 \mathrm{ab}$ \\
\hline DALZ 0102 & 113.5 & 96.8 & $3.4 \mathrm{ab}$ & $2.4 \mathrm{ab}$ & $1.4 \mathrm{~b}$ & $11.5 \mathrm{ab}$ \\
\hline Meyer & 127.5 & 117.8 & $2.3 \mathrm{~b}$ & $1.5 \mathrm{~b}$ & $4.0 \mathrm{~b}$ & $6.8 \mathrm{ab}$ \\
\hline \multicolumn{7}{|c|}{$\begin{array}{l}\text { Values show percentage of pixels representing large patch symptoms from digital images taken of plots of } \\
\text { each zoysiagrass line and averaged across three replicated plots per line. The plots were inoculated in the } \\
\text { fall of } 2008 \text {. One-way analysis of variance was used to compare average patch diameter and percentage of } \\
\text { diseased turf. Values followed by the same letter in a column are not statistically different }(P<0.05) \text {. } \\
\text { Values in the same column and with no letters are not statistically different }(P<0.05) \text {. } \\
{ }^{y} \text { Meyer, DALZ } 0102 \text {, and Anderson (Chinese common) are } Z \text {. japonica. Zorro, 8501, 8508, and Diamond } \\
\text { are } Z \text {. matrella. } \\
\text { 'Area under disease progress curve for the percentage of diseased turf. Calculated as } \sum\left[\left(y_{i}+y_{i+1}\right) / 2\right]\left[t_{i+1}-t_{i}\right] \text {, } \\
\text { where } i=1,2,3, \ldots, n-1, y_{\mathrm{i}} \text { is the amount of disease (percentage of diseased turf) and } t_{i} \text { is the time of the } i \text { th } \\
\text { rating. Values followed by same letter in a column are not statistically different }(P<0.05) \text {. There was no } \\
\text { significant difference in patch size among progeny and Meyer on } 12 \text { and } 19 \text { June. }\end{array}$} \\
\hline
\end{tabular}

Table 4. Percentage of large patch (caused by R. solani AG 2-2 LP) diseased turf of new zoysiagrass lines and 'Meyer' under field conditions at Manhattan, KS, in 2010.

\begin{tabular}{|c|c|c|c|c|c|}
\hline \multirow[b]{2}{*}{ Progeny/parent ${ }^{\mathrm{y}}$} & \multicolumn{4}{|c|}{ Percentage of diseased turf ${ }^{2}$} & \multirow[b]{2}{*}{ AUDPC $^{x}$} \\
\hline & 1 May & 7 May & 28 May & 24 June & \\
\hline \multicolumn{6}{|c|}{ Cavalier $\times$ Chinese Common } \\
\hline $5311-16$ & $28.6 \mathrm{ef}$ & $27.2 \mathrm{de}$ & 36.6 de & $17.1 \mathrm{bc}$ & $86.7 \mathrm{ef}$ \\
\hline $5312-55$ & $38.0 \mathrm{cdef}$ & 39.9 cde & 47.0 bcde & $9.5 \mathrm{c}$ & $110.6 \mathrm{def}$ \\
\hline \multicolumn{6}{|l|}{ Zorro $\times$ Meyer } \\
\hline $5313-23$ & $61.3 \mathrm{abcd}$ & $46.1 \mathrm{cde}$ & 45.3 bcde & $8.6 \mathrm{c}$ & $126.4 \mathrm{cdef}$ \\
\hline $5313-34$ & 48.4 bcdef & $43.8 \mathrm{cde}$ & 48.4 bcde & $11.6 \mathrm{bc}$ & $122.2 \mathrm{def}$ \\
\hline $5313-71$ & $79.9 \mathrm{a}$ & $80.2 \mathrm{a}$ & $77.9 \mathrm{a}$ & $39.7 \mathrm{a}$ & $217.9 \mathrm{a}$ \\
\hline $5313-46$ & $77.2 \mathrm{a}$ & $72.2 \mathrm{ab}$ & $76.8 \mathrm{a}$ & $12.3 \mathrm{bc}$ & $193.9 \mathrm{ab}$ \\
\hline \multicolumn{6}{|l|}{ Emerald $\times$ Meyer } \\
\hline $5321-9$ & $58.1 \mathrm{abcd}$ & $50.8 \mathrm{bcd}$ & 43.9 cde & $15.3 \mathrm{bc}$ & $131.4 \mathrm{cde}$ \\
\hline $5321-18$ & $27.8 \mathrm{ef}$ & 35.2 cde & $54.9 \mathrm{bcd}$ & $18.4 \mathrm{bc}$ & $113.2 \mathrm{def}$ \\
\hline \multicolumn{6}{|l|}{ Meyer $\times 8501$} \\
\hline $5324-26$ & 52.8 abcde & $45.6 \mathrm{cde}$ & $53.7 \mathrm{bcd}$ & $14.3 \mathrm{bc}$ & $132.8 \mathrm{cde}$ \\
\hline $5324-32$ & $61.7 \mathrm{abcd}$ & 47.8 bcde & $65.9 \mathrm{ab}$ & $11.1 \mathrm{bc}$ & $150.1 \mathrm{bcd}$ \\
\hline \multicolumn{6}{|l|}{ Meyer $\times 8508$} \\
\hline $5325-11$ & $64.6 \mathrm{abc}$ & $58.7 \mathrm{abc}$ & $60.4 \mathrm{abc}$ & $18.0 \mathrm{bc}$ & $160.4 \mathrm{bcd}$ \\
\hline \multicolumn{6}{|l|}{ Meyer $\times$ Diamond } \\
\hline $5327-67$ & $70.1 \mathrm{ab}$ & $72.3 \mathrm{ab}$ & $66.0 \mathrm{ab}$ & $14.1 \mathrm{bc}$ & $180.4 \mathrm{abc}$ \\
\hline \multicolumn{6}{|l|}{ Emerald $\times$ Zenith } \\
\hline $5334-59$ & $35.2 \mathrm{def}$ & $29.8 \mathrm{de}$ & 49.4 bcde & $27.2 \mathrm{ab}$ & $110.4 \mathrm{def}$ \\
\hline DALZ 0102 & 53.4 abcde & $57.3 \mathrm{abc}$ & 52.1 bcde & $13.2 \mathrm{bc}$ & $142.7 \mathrm{bcd}$ \\
\hline Meyer & $20.14 \mathrm{f}$ & $23.5 \mathrm{e}$ & $31.0 \mathrm{e}$ & $19.8 \mathrm{bc}$ & $74.5 \mathrm{f}$ \\
\hline
\end{tabular}

${ }^{\mathrm{z}}$ Values are percentage of pixels representing large patch symptoms from digital images taken of plots of each zoysiagrass line and averaged across three replicated plots per line. The plots were inoculated in the fall of 2008. One-way analysis of variance was used to compare the percentage of diseased turf. Values followed by the same letter in a column are not statistically different $(P<0.05)$. Values in the same column and with no letters are not statistically different $(P<0.05)$.

${ }^{y}$ Meyer, DALZ 0102, and Anderson (Chinese common) are Z. japonica. Zorro, 8501, 8508, and Diamond are Z. matrella.

${ }^{\mathrm{x}}$ Area under disease progress curve for the percentage of diseased turf. Calculated as $\sum\left[\left(y_{i}+y_{i+1}\right) / 2\right]\left[t_{i+1}-t_{i}\right]$, where $i=1,2,3, \ldots, n-1, y_{\mathrm{i}}$ is the amount of disease (percentage of diseased turf) and $t_{i}$ is the time of the $i$ th rating. Values followed by same letter in a column are not statistically different $(P<0.05)$. progeny in 2009 , and in 2010 , two of the three progeny had lower AUDPC values than 5313-34 and 5313-46. Although all progeny performed comparably with 'Meyer' under field conditions in 2009, results from the 2010 field study indicated that only six progeny had AUDPC large patch levels as low as 'Meyer'. Importantly, we found no correlation between results with large patch susceptibility in the growth chamber compared with results in the field. More work is needed to determine the usefulness of growth chamber evaluations in determining zoysiagrass susceptibility to large patch.

This study represents the first report of the evaluation of these new zoysiagrass progeny lines for their susceptibility to large patch disease. The lack of correlation between growth chamber and field studies is suggestive of differences in important environmental conditions to which the plants were subject during the experiments. Such natural variations in field environmental conditions and their accompanying effects on the plantpathogen interaction indicate the need for additional years of evaluation of the progeny under field conditions. Additional studies are required to further evaluate their performance under field conditions at other locations.

\section{Literature Cited}

Brunneau, A. 2005. NTEP Zoysiagrass cultivar evaluation report. p. 63-64.

Carling, D.E. 1996. Grouping in Rhizoctonia solani by hyphal anastomosis, p. 37-47. In: Sneh, B., S. Jabaji-Hare, S. Neate, and G. Dijst (eds.). Rhizoctonia species: Taxonomy, molecular biology, ecology, pathology, and disease control. Kluwer Academic Publishers, Dordrecht, The Netherlands.

Carling, D.E., S. Kuninaga, and K.A. Brainard. 2002. Hyphal anastomosis reactions, rDNAinternal transcribed spacer sequences, and virulence levels among subsets of Rhizoctonia solani anastomosis group-2 (AG-2) and AG-BI. Phytopathology 92:43-50.

Dunn, J.H. and K. Diesburg. 2004. Turf management in the transition zone. John Wiley and Sons, Inc., Hoboken, NJ.

Fry, J., M. Kennelly, and R. St. John. 2008 Zoysiagrass: Economic and environmental sense in the transition zone. Golf Course Management May:127-132.

Fry, J.D. and R.A. Cloyd. 2011. Zoysiagrass genotypes differ in susceptibility to the bluegrass billbug, Sphenophorus parvulus. HortScience 46:1314-1316.

Fry, J.D. and P. Dernoeden. 1987. Growth of zoysiagrass from vegetative plugs in response to fertilizers. J. Amer. Soc. Hort. Sci. 112:286289.

Fry, J.D. and B. Huang. 2004. Applied turfgrass science and physiology. John Wiley \& Sons, Hoboken, NJ.

Green, D.E., II, J.D. Fry, J.C. Pair, and N.A Tisserat. 1993. Pathogenicity of Rhizoctonia solani AG 2-2 and Ophiosphaerella herpotricha on zoysiagrass. Plant Dis. 77:1040-1044.

Karcher, D.E. and M.D. Richardson. 2005. Batch analysis of digital images to evaluate turfgrass characteristics. Crop Sci. 45:1536-1539.

Madden, L.V., G. Hughes, and F. van den Bosch. 2007. The study of plant disease epidemics. APS Press, St. Paul, MN. 
Martin, B. 1987. Rapid tentative identification of Rhizoctonia spp. associated with diseased turfgrasses. Plant Dis. 71:47-49.

Martin, S.B. and L.T. Lucas. 1984. Characterization and pathogenicity of Rhizoctonia spp. and binucleate Rhizoctonia-like fungi from turf grasses in North Carolina. Phytopathology 74 : $170-175$.

Metz, S.P., P.F. Colbaugh, and M.C. Engelke. 1993. Rhizoctonia blight susceptibility among commercial and experimental zoysiagrasses. Texas Turfgr. Res. Consolidated Prog. Rep. Texas Turfgr. Res. Consolidated Prog. Rep. PR-5129. Texas Agric. Exp. Stn., Texas A\&M Univ., College Station, TX. p. 82-83.

Okeyo, D.O., J.D. Fry, D. Bremer, C.B. Rajashekar, M. Kennelly, A. Chandra, D.A. Genovesi, and
M.C. Engelke. 2011. Freezing tolerance and seasonal color of experimental zoysiagrasses. Crop Sci. 51:2858-2863.

Patton, A.J., S.M. Cunningham, J.J. Volenec, and Z.J. Reicher. 2007. Differences in freeze tolerance of zoysiagrasses: II. Carbohydrates and proline accumulation. Crop Sci. 47:2170 2181.

Patton, A.J. and Z.J. Reicher. 2007. Zoysiagrass species and genotypes differ in their winter injury and freeze tolerance. Crop Sci. 47:1619-1627.

Reicher, Z. 2004. NTEP Zoysiagrass cultivar evaluation report. p. 39-40.

Reicher, Z. 2006. NTEP Zoysiagrass cultivar evaluation report. p. 52-53.

Smiley, R.W., P.H. Dernoeden, and B.B. Clarke. 2005. Compendium of turfgrass disease.
American Phytopathological Society Press, MN. p. 80

Tisserat, N.A., J.D. Fry, and D.E.I.I. Green. 1994 Managing Rhizoctonia large patch. Golf Course Management June:58-61.

Tisserat, N.A., J.C. Pair, and A. Nus. 1989 Ophiosphaerella herpotricha, a cause of spring dead spot of bermudagrass in Kansas. Plant Dis. 73:933-937.

Zhang, Q. 2007. Freezing tolerance in zoysiagrass. An abstract of a dissertation. <http://www.krex. k-state.edu/hdl.handle.net/2097/448>.

Zhang, Q. and J.D. Fry. 2006. Preliminary evaluation of freezing tolerance of Meyer and DALZ 0102 zoysiagrass. In: K-State turfgrass research, 2006: Progress report. 962. Kansas Agric. Exp. Stn., Kansas State Univ., Manhattan, KS. 